\title{
New Mediators in the Biology of the Ductus Arteriosus: Lessons from the Chicken Embryo
}

\author{
Saskia van der Sterren, Riazudin Mohammed, \\ and Eduardo Villamor
}

\begin{abstract}
The chicken embryo is an ideal model for the study of new hypotheses on the developmental biology of ductus arteriosus (DA). A unique characteristic of chicken DA is that it is the result of the fusion of two vessels with different embryological origins, morphologies, and functionalities. The pulmonary side (PulmDA) consists almost exclusively of neural crest-derived cells, shows the structure of a muscular artery, and responds to $\mathrm{O}_{2}$ with contraction whereas the aortic part is of mesodermal origin, shows the morphology of an elastic artery and relaxes in response to $\mathrm{O}_{2}$. In addition the two parts of the DA show marked differences in responsiveness to other contractile and relaxant agents.

In mammals, the most accepted model of $\mathrm{O}_{2}$-induced DA constriction involves a rise in $\mathrm{O}_{2}$ modulating the function of the mitochondrial electron transport chain (the sensor), leading to an increased production of $\mathrm{H}_{2} \mathrm{O}_{2}$ (the mediator) that causes the inhibition of $\mathrm{K}_{\mathrm{V}}$ channels (the effector) with Rho kinase acting as another downstream effector of the $\mathrm{O}_{2}$-sensing system in the DA. In the chicken embryo, we verified the very same pathway, proving a conserved mechanism for $\mathrm{O}_{2}$ sensing/signaling in mammalian and nonmammalian DA. Moreover, we demonstrated a developmentally regulated response to $\mathrm{O}_{2}$, which is restricted to the mature PulmDA and involves parallel maturation of the three components: sensor, mediator, and effectors. Besides $\mathrm{O}_{2}$, we used the chicken embryo model to investigate the possible ductal effects of vasoactive mediators such as ceramide, $\mathrm{H}_{2} \mathrm{~S}$, isoprostanes, or platelet-derived vasoactive mediators.
\end{abstract}

\section{Keywords}

Ductus arteriosus $\cdot$ Oxygen sensing $\cdot \mathrm{H}_{2} \mathrm{~S} \cdot$ Isoprostanes $\cdot$ Ceramide

S. van der Sterren $\cdot$ R. Mohammed $\cdot$ E. Villamor $(\varangle)$

Department of Pediatrics, Maastricht University Medical Center (MUMC+),

School for Oncology and Developmental Biology (GROW), Maastricht, The Netherlands

e-mail: E.Villamor@mumc.nl 


\subsection{The Chicken Embryo as a Model for Ductus Arteriosus' Developmental Biology}

Several mammalian models have helped to unravel the biology and pathobiology of the ductus arteriosus (DA) and to understand the factors responsible for its closure or patency after birth. However, these models are technically complex and experimental manipulations affect both the mother and the fetus [1,2]. Therefore, there is a need for additional models, addressing these limitations. In the last years, the chicken embryo has emerged as a suitable model for the study of DA vascular biology [3-15].

A unique characteristic of chicken DA is that it is the result of the fusion of two vessels with different embryological origins, morphologies, and functionalities [1, $3,6,7]$. The pulmonary side (PulmDA) consists almost exclusively of neural crestderived cells, shows the structure of a muscular artery, and responds to $\mathrm{O}_{2}$ with contraction whereas the aortic part (AoDA) is of mesodermal origin, shows the morphology of an elastic artery and relaxes in response to $\mathrm{O}_{2}[1,3,6,7]$. The two parts of the DA show marked differences in responsiveness not only to $\mathrm{O}_{2}$ but to other contractile and relaxant agents as well $[4,5]$. These differences are summarized in Table 35.1. Another advantage of the chicken DA model is that we have an exhaustive developmental calendar. The developmental changes in PulmDA responsiveness to contractile and relaxant agents are summarized in Table 35.2.

Table 35.1 Effect of vasoactive mediators in the pulmonary (PulmDA) and the aortic (AoDA) side of chicken DA

\begin{tabular}{|c|c|c|c|c|c|}
\hline Vasoactive agent & Nature or mechanism of action & $\begin{array}{l}\text { Effect in } \\
\text { PulmDA }\end{array}$ & & Effect in AoDA & Ref. \\
\hline Oxygen & Gaseous mediator & Contraction & $\neq$ & Relaxation & [3] \\
\hline $\mathrm{KCl}$ & Depolarizing agent & Contraction & $<$ & Contraction & {$[3]$} \\
\hline $\mathrm{PGE}_{2}$ & Prostaglandin & Contraction $^{\mathrm{a}}$ & $>$ & Contraction & [4] \\
\hline Norepinephrine & Adrenoceptor agonist & Contraction & $>$ & Contraction & [3] \\
\hline U46619 & $\mathrm{TP}$ receptor agonist & Contraction & $>$ & Contraction & [3] \\
\hline Isoproterenol & $\beta$-Adrenoceptor agonist & Relaxation & $>$ & Relaxation & [4] \\
\hline Forskolin & Adenylyl cyclase activator & Relaxation & $>$ & Relaxation & [4] \\
\hline Milrinone & Phosphodiesterase- 3 inhibitor & Relaxation & $>$ & Relaxation & [4] \\
\hline Acetylcholine & Muscarinic agonist & Relaxation $^{\mathrm{b}}$ & $<$ & Relaxation & {$[5]$} \\
\hline SNP & NO-donor & Relaxation & $<$ & Relaxation & [5] \\
\hline BAY 41-2272 & sGC stimulator & Relaxation & $<$ & Relaxation & {$[5]$} \\
\hline $\mathrm{CO}_{2}$ & Gaseous mediator & Relaxation & $=$ & Relaxation & [8] \\
\hline $15-\mathrm{E}_{2 \mathrm{t}}$-IsoP & Isoprostane & Contraction & $>$ & Contraction & [14] \\
\hline $15-\mathrm{F}_{2 \mathrm{t}}$-IsoP & Isoprostane & Contraction & $>$ & Contraction & [14] \\
\hline $\mathrm{H}_{2} \mathrm{O}_{2}$ & Reactive oxygen species & Contraction & $\neq$ & Relaxation & [6] \\
\hline Hydroxyfasudil & Rho-kinase inhibitor & Relaxation & $=$ & Relaxation & [6] \\
\hline Y27632 & Rho-kinase inhibitor & Relaxation & $=$ & Relaxation & [6] \\
\hline $\mathrm{CO}$ & Gaseous mediator & Relaxation & $=$ & Relaxation & [13] \\
\hline $\mathrm{H}_{2} \mathrm{~S}$ & Gaseous mediator & Relaxation & $=$ & Relaxation & [13] \\
\hline $17 \alpha$-estradiol & Estrogen hormone & Relaxation & $=$ & Relaxation & [15] \\
\hline $17 \beta$-estradiol & Estrogen hormone & Relaxation & $=$ & Relaxation & [15] \\
\hline Ceramide & Membrane sphingolipid & Contraction & $\neq$ & Relaxation & [9] \\
\hline Serotonin & Amine & Contraction & $>$ & Contraction & [16] \\
\hline Thrombin & Protease & Contraction & $>$ & Contraction & [18] \\
\hline
\end{tabular}

${ }^{\mathrm{a}}$ In the presence of TP receptor blockade, $\mathrm{PGE}_{2}$ evokes relaxation

${ }^{\mathrm{b}}$ Concentrations $>3 \mu \mathrm{M}$ of acetylcholine evoke contraction 
Table 35.2 Developmental changes in the response of chicken DA (pulmonary side) to vasoactive mediators

\begin{tabular}{|c|c|c|c|c|c|c|c|}
\hline Vasoactive agent & $\begin{array}{l}\text { Nature/mechanism } \\
\text { of action }\end{array}$ & 15-day DA & & 19-day DA & & 21-day DA & Ref. \\
\hline Oxygen & Gaseous mediator & No response & $\neq$ & Contraction & $<$ & Contraction & [3] \\
\hline $\mathrm{KCl}$ & Depolarizing agent & Contraction & $<$ & Contraction & $<$ & Contraction & [3] \\
\hline 4-AP & $\mathrm{K}_{\mathrm{V}}$-channel blocker & Contraction & $<$ & Contraction & $<$ & Contraction & [3] \\
\hline Norepinephrine & Adrenoceptor agonist & No response & $\neq$ & Contraction & $<$ & Contraction & [3] \\
\hline Phenylephrine & $\begin{array}{l}\alpha \text {-Adrenoceptor } \\
\text { agonist }\end{array}$ & No response & $\neq$ & Contraction & $<$ & Contraction & [3] \\
\hline U46619 & TP receptor agonist & Contraction & $<$ & Contraction & $=$ & Contraction & [3] \\
\hline Endothelin-1 & Polypeptide & Contraction & $<$ & Contraction & $>$ & Contraction & [3] \\
\hline $\mathrm{ACh}(\geq 3 \mu \mathrm{M})$ & Muscarinic agonist & Contraction & $<$ & Contraction & $>$ & Contraction & [10] \\
\hline $\mathrm{PGE}_{2}$ & Prostaglandin & Relaxation & $\neq$ & Contraction & $\neq$ & No response & [4] \\
\hline $\begin{array}{l}\mathrm{PGE}_{2} \\
\text { (+TP-blockade) }\end{array}$ & Prostaglandin & Relaxation & $>$ & Relaxation & $>$ & Relaxation & [4] \\
\hline $\begin{array}{l}\text { Acetylcholine } \\
(<3 \mu \mathrm{M})\end{array}$ & Muscarinic agonist & Relaxation & $>$ & Relaxation & $>$ & Relaxation & [5] \\
\hline SNP & NO-donor & Relaxation & $=$ & Relaxation & $>$ & Relaxation & [5] \\
\hline Isoproterenol & $\begin{array}{l}\beta \text {-Adrenoceptor } \\
\text { agonist }\end{array}$ & Relaxation & $=$ & Relaxation & $>$ & Relaxation & [4] \\
\hline BAY 41-2272 & sGC stimulator & Relaxation & $=$ & Relaxation & $=$ & Relaxation & [5] \\
\hline 8-Br cGMP & cGMP analog & Relaxation & $=$ & Relaxation & $=$ & Relaxation & [5] \\
\hline Forskolin & $\begin{array}{l}\text { Adenylyl cyclase } \\
\text { activator }\end{array}$ & Relaxation & $=$ & Relaxation & $=$ & Relaxation & [4] \\
\hline Milrinone & $\begin{array}{l}\text { Phosphodiesterase-3 } \\
\text { inhibitor }\end{array}$ & Relaxation & $<$ & Relaxation & $=$ & Relaxation & [4] \\
\hline $\mathrm{H}_{2} \mathrm{O}_{2}$ & ROS & No response & $\neq$ & Contraction & & & [6] \\
\hline BAY K8644 & $\begin{array}{l}\text { Calcium-channel } \\
\text { activator }\end{array}$ & No response & $\neq$ & Contraction & & & [6] \\
\hline Nifedipine & $\begin{array}{l}\text { Calcium-channel } \\
\text { blocker }\end{array}$ & Relaxation & $<$ & Relaxation & & & [6] \\
\hline Hydroxyfasudil & Rho-kinase inhibitor & Relaxation & $<$ & Relaxation & & & [6] \\
\hline Y 27632 & Rho-kinase inhibitor & Relaxation & $<$ & Relaxation & & & [6] \\
\hline $\mathrm{H}_{2} \mathrm{~S}$ & Gaseous mediator & Relaxation & $=$ & Relaxation & & & [13] \\
\hline $\mathrm{CO}$ & Gaseous mediator & Relaxation & $=$ & Relaxation & & & [13] \\
\hline $15-\mathrm{E}_{2 \mathrm{t}}$-IsoP & Isoprostane & Contraction & $<$ & Contraction & & & [14] \\
\hline $15-\mathrm{F}_{2 \mathrm{t}}$-IsoP & Isoprostane & Contraction & $<$ & Contraction & & & [14] \\
\hline
\end{tabular}

\subsection{Oxygen Sensing and Signaling in the Chicken DA}

In mammals, the most accepted model of $\mathrm{O}_{2}$-induced DA constriction involves a rise in $\mathrm{O}_{2}$ modulating the function of the mitochondrial electron transport chain (the sensor), leading to an increased production of $\mathrm{H}_{2} \mathrm{O}_{2}$ (the mediator) that causes the inhibition of $\mathrm{K}_{\mathrm{V}}$ channels (the effector) with Rho kinase acting as another downstream effector of the $\mathrm{O}_{2}$-sensing system in the DA. In the chicken embryo the very same pathway has been verified, proving a conserved mechanism for $\mathrm{O}_{2}$ sensing/ signaling in mammalian and nonmammalian DA $[1,6,7]$. Moreover, we demonstrated a developmentally regulated response to $\mathrm{O}_{2}$, which is restricted to the mature PulmDA and involves parallel maturation of the three components: sensor, mediator, and effectors [6]. 


\subsection{New Mediators in the Biology of the DA}

\subsubsection{Role of Ceramide in DA Oxygen Sensing and Signaling}

Ceramide is synthesized from membrane sphingomyelin by sphingomyelinases (SMases) which are activated by multiple membrane receptors and non-receptor stimuli. Using the chicken model, we observed that inhibition of the ceramide-generating enzyme neutral SMase reduced the hypoxic vasoconstriction in the pulmonary artery (PA) and the normoxic contraction of the DA [9]. Moreover, ceramide content and $\mathrm{H}_{2} \mathrm{O}_{2}$ production were increased by hypoxia in PAs and by normoxia in the DA. Accordingly, ceramide mimicked the contractile responses of hypoxia in PAs and those of normoxia in the DA. In addition, ceramide inhibited Kv currents in PA and DA smooth muscle cells. Finally, the role of nSMase in acute oxygen sensing was confirmed in human PA and DA [12]. However, the mechanisms matching the putative $\mathrm{O}_{2}$ sensor(s) (i.e., mitochondria and/or NADPH oxidase) and ceramide remain unknown.

\subsubsection{Vasoactivity of $\mathrm{H}_{2} \mathrm{~S}$ in the Chicken DA}

Oxygen is not the only gaseous mediator with a relevant role in DA reactivity. $\mathrm{CO}_{2}$ and non-respiratory gases, such as $\mathrm{NO}$ and $\mathrm{CO}$, are also ductal vasoactive mediators $[1,16]$. In the last years $\mathrm{H}_{2} \mathrm{~S}$ has been identified as an endogenous gaseous transmitter, playing multiple physiological roles in animal systems [13]. Furthermore, $\mathrm{H}_{2} \mathrm{~S}$ has been proposed as a vascular $\mathrm{O}_{2}$ sensor. We have investigated the vasoactivity of $\mathrm{H}_{2} \mathrm{~S}$ and $\mathrm{CO}$ in the chicken DA. We observed that either $\mathrm{H}_{2} \mathrm{~S}$ or $\mathrm{CO}$ induces relaxation of chicken DA. However, this relaxation is not vessel-specific since PulmDA, AoDA, and chicken embryo pulmonary and femoral arteries were similarly relaxed by $\mathrm{H}_{2} \mathrm{~S}$ and $\mathrm{CO}$ [13]. Moreover, the presence of precursors/inhibitors of $\mathrm{H}_{2} \mathrm{~S}$ and $\mathrm{CO}$ synthesis did not significantly affect the response of the chicken DA to normoxia/ hypoxia and did not affect endothelium-dependent or -independent relaxation [13]. Therefore, our results indicate that the gasotransmitters $\mathrm{H}_{2} \mathrm{~S}$ and $\mathrm{CO}$ are vasoactive in the chicken DA but they do not suggest an important role for endogenous $\mathrm{H}_{2} \mathrm{~S}$ or $\mathrm{CO}$ in the control of chicken ductal reactivity.

\subsubsection{Response of Chicken DA to Isoprostanes}

Isoprostanes (IsoPs) are a unique series of prostaglandin-like compounds formed in vivo from the free radical-catalyzed peroxidation of arachidonic acid independent of the cyclooxygenase enzymes [17]. Initially, IsoPs were recognized as valuable markers of oxidative stress and numerous pathological conditions have been shown to be associated with increases in urinary, plasma, and tissue levels of IsoPs. Later it became apparent that IsoPs exhibit significant bioactivity and could contribute to the functional consequences of oxidative stress and participate in oxygen signaling, particularly during the transition to extra-uterine life [17]. Surprisingly, 
until our study, the possible vascular effects of IsoPs in the DA had not been investigated. We observed that $15-\mathrm{E}_{2 \mathrm{t}}$-IsoP evoked a potent and efficacious, TP receptormediated, contraction in the chicken DA [18]. On the other hand, 15- $\mathrm{F}_{2 \mathrm{t}} \mathrm{-I}$ soP is probably acting as a partial agonist at TP receptors. The contractile response of the PulmDA to IsoPs increased with development and both $15-\mathrm{E}_{2 \mathrm{t}}-\mathrm{IsoP}$ and $15-\mathrm{F}_{2 \mathrm{t}}$-IsoP were particularly efficacious in contracting the PulmDA in comparison with the AoDA and the femoral or the pulmonary arteries [14]. Altogether, our data suggest that IsoPs, acting through TP receptors, may play a role in the control of chicken DA tone and could participate in its closure.

\subsubsection{Role of Platelet-Derived Vasoactive Mediators in DA Biology}

Several cohort studies have shown an association between low platelet counts in the first day(s) of life and patent DA (PDA) in preterm infants [19]. Activated platelets release different substances with vasoactive properties, like serotonin, thromboxane $\mathrm{A}_{2}$ (TXA $)$, platelet activating factor, or thrombin. The two former agonists are vasoactive in the chicken DA $[10,16]$. In addition, we investigated the possible vasoactive effects of thrombin in the DA. Cellular effects of thrombin are mediated by proteaseactivated receptors (PARs), members of the G-protein-coupled receptors that carry their own ligand, which remains cryptic until unmasked by proteolytic cleavage. PAR-1 and PAR-2 have been shown to be involved in regulating vascular tone. Our preliminary results indicate that thrombin, acting through PAR-1, is a selective vasoconstrictor in the DA of the chicken, providing the first functional evidence for a role of PARs in DA biology [18]. Currently, we are analyzing the expression of PARs in the DA of several species (human, lamb, rat, mouse, and chicken).

\subsection{Future Direction and Clinical Implications}

The hope for future targeted therapies and for the prevention of patent DA (PDA) requires knowledge of the fundamental mechanisms controlling its development and pathogenesis [20]. In addition, new drugs or even those that are commonly used in the neonatal intensive care unit may have unexpected effects on the ability of the DA to spontaneously close, resulting in increased risks for PDA [20]. The chicken DA is a feasible model to test the possible ductal effects of drugs or therapeutic strategies to which the infants are exposed in utero or after birth.

\section{References}

1. Dzialowski EM, Sirsat T, van der Sterren S, et al. Prenatal cardiovascular shunts in amniotic vertebrates. Respir Physiol Neurobiol. 2011;178:66-74.

2. Itani N, Salinas CE, Villena M, et al. The highs and lows of programmed cardiovascular disease by developmental hypoxia: studies in the chicken embryo. J Physiol. 2018;596(15):2991-3006. 
3. Agren P, Cogolludo AL, Kessels CG, et al. Ontogeny of chicken ductus arteriosus response to oxygen and vasoconstrictors. Am J Physiol Regul Integr Comp Physiol. 2007;292:R485-96.

4. Agren P, van der Sterren S, Cogolludo AL, et al. Developmental changes in the effects of prostaglandin E2 in the chicken ductus arteriosus. J Comp Physiol B. 2009;179:133-43.

5. Agren P, van der Sterren S, Cogolludo AL, et al. Developmental changes in endotheliumdependent relaxation of the chicken ductus arteriosus. J Physiol Pharmacol. 2008;59:55-76.

6. Cogolludo AL, Moral-Sanz J, van der Sterren S, et al. Maturation of O2 sensing and signaling in the chicken ductus arteriosus. Am J Physiol Lung Cell Mol Physiol. 2009;297:L619-30.

7. Greyner H, Dzialowski EM. Mechanisms mediating the oxygen-induced vasoreactivity of the ductus arteriosus in the chicken embryo. Am J Physiol Regul Integr Comp Physiol. 2008;295:R1647-59.

8. Moonen RM, Agren P, Cogolludo AL, et al. Response of chicken ductus arteriosus to hypercarbic and normocarbic acidosis. Neonatology. 2010;98:47-56.

9. Moreno L, Moral-Sanz J, Morales-Cano D, et al. Ceramide mediates acute oxygen sensing in vascular tissues. Antioxid Redox Signal. 2014;20:1-14.

10. Schuurman MJ, Villamor E. Endothelium-dependent contraction induced by acetylcholine in the chicken ductus arteriosus involves cyclooxygenase-1 activation and TP receptor stimulation. Comp Biochem Physiol A Mol Integr Physiol. 2010;157:28-34.

11. Van der Sterren S, Agren P, Zoer B. Morphological and functional alterations of the ductus arteriosus in a chicken model of hypoxia-induced fetal growth retardation. Pediatr Res. 2009;65:279-84.

12. Van der Sterren S, Kessels L, Perez-Vizcaino F, et al. Prenatal exposure to hyperoxia modifies the thromboxane prostanoid receptor-mediated response to $\mathrm{H} 2 \mathrm{O} 2$ in the ductus arteriosus of the chicken embryo. J Physiol Pharmacol. 2014;65:283-93.

13. Van der Sterren S, Kleikers P, Zimmermann LJ, Villamor E. Vasoactivity of the gasotransmitters hydrogen sulfide and carbon monoxide in the chicken ductus arteriosus. Am J Physiol Regul Integr Comp Physiol. 2011;301:R1186-98.

14. van der Sterren S, Villamor E. Contractile effects of 15-E2t-isoprostane and 15-F2t-isoprostane on chicken embryo ductus arteriosus. Comp Biochem Physiol A Mol Integr Physiol. 2011;159:436-44.

15. Flinsenberg TW, van der Sterren S, van Cleef AN, et al. Effects of sex and estrogen on chicken ductus arteriosus reactivity. Am J Physiol Regul Integr Comp Physiol. 2010;298:R1217-24.

16. van Zogchel L, Villamor E. Serotonin is a selective vasoconstrictor of chicken embryo ductus arteriosus. Arch Dis Child. 2014;99:A620.

17. Belik J, González-Luis GE, Perez-Vizcaino F, et al. Isoprostanes in fetal and neonatal health and disease. Free Radic Biol Med. 2010;48:177-88.

18. Kartal K, Meekels J, Mohammed R, et al. Protease-activated receptor (PAR)-mediated contraction of the chicken ductus arteriosus. Arch Dis Child. 2012;97:A325.

19. Simon SR, Van Zogchel L, Bas-Suárez MP, et al. Platelet counts and patent ductus arteriosus in preterm infants: a systematic review and meta-analysis. Neonatology. 2015;108:143-51.

20. Stoller JZ, DeMauro SB, Dagle JM, et al. Current perspectives on pathobiology of the ductus arteriosus. J Clin Exp Cardiolog. 2012;8:S8-001. 
Open Access This chapter is licensed under the terms of the Creative Commons Attribution 4.0 International License (http://creativecommons.org/licenses/by/4.0/), which permits use, sharing, adaptation, distribution and reproduction in any medium or format, as long as you give appropriate credit to the original author(s) and the source, provide a link to the Creative Commons license and indicate if changes were made.

The images or other third party material in this chapter are included in the chapter's Creative Commons license, unless indicated otherwise in a credit line to the material. If material is not included in the chapter's Creative Commons license and your intended use is not permitted by statutory regulation or exceeds the permitted use, you will need to obtain permission directly from the copyright holder. 